\title{
Partnership inside Governance Spaces: the case of the Municipal Development Forum of Igarapé-Açú, Pará, Amazonia
}

\author{
MÁRIO VASCONCELLOS SOBRINHO \\ Universidade da Amazônia (UnAMA) e Universidade Federal do Pará (UFPA), Belém - PA, Brasil \\ marco antonio Carvalho Teixeira \\ Fundação Getulio Vargas / Escola de Administração de Empresas de SÃo Paulo, SÃo Paulo - SP, Brasil
}

\begin{abstract}
This paper discusses how partnership between local organisations and Government inside governance spaces affects local development. The aim is to raise some critical issues about the concept of partnership and about partnership effectively for municipal development. Thus, the article uses partnership as its central theory. Specifically, it explores to what extent partnership is an effective strategy for local development in areas of historical conflict between local Government and local organisations in Pará State, Brazilian Amazonia. It focuses particularly on the municipality of Igarapé-Açú, located in north-east of Pará State. Igarapé-Açú was chosen because it is a singular case of local organisations and Government partnership since 2008 when a governance space was created to carry out a partnership process called Municipal Development Forum (MDF). Methodologically, the case study was carried out from a qualitative analysis with data gathered from documents and semi-structured interviews with key-informants. The paper shows that the great challenge to build partnerships between local Government and local organisations is not in these actors capacity to represent the state and civil society in a governance forum, but in their capacity to change the local institutional environment to enable this forum to propose changes in terms of rural development. The paper shows that institutional change does not happen rapidly; changes depend on a particular historical context. In conclusion, the case of Igarapé-Açú shows that in an environment where there is great political conflict much time is needed to create links between the rural actors.
\end{abstract}

Keywords: Partnership. Governance Space. Rural Development. Municipal Development.

\section{Parceria em Espaços de Governança: o caso do Fórum Municipal de Desenvolvimento de Igarapé-Açú, Pará, Amazônia} Resumo

O artigo discute como a parceria entre governo e organizações locais em espaços de governança afetam o desenvolvimento local. O objetivo é levantar pontos críticos sobre o conceito de parceria e sobre a efetividade da parceria para o desenvolvimento municipal. Assim, o artigo utiliza a parceria como teoria central. De forma específica, a pesquisa analisa em que medida a parceria é uma estratégia efetiva para o desenvolvimento local em áreas historicamente marcadas por conflitos entre o governo e organizações locais no estado do Pará, na Amazônia brasileira. O estudo foca-se particularmente no município de Igarapé-Açú, localizado ao nordeste do estado do Pará. Este município foi escolhido por ser um caso singular de parceria entre governo e organizações locais desde 2008 quando foi criado um espaço de governança para estabelecer um processo de parceria, denominado Fórum de Desenvolvimento Municipal (FDM). Metodologicamente, o estudo de caso foi realizado a partir de uma análise qualitativa com dados obtidos por meio de documentos e entrevistas semiestruturadas com informanteschaves. O artigo demonstra que o grande desafio para a construção de parceria entre governo e organizações locais não está na capacidade destes representarem o Estado e a sociedade civil em um fórum de governança, mas em sua capacidade de mudar o ambiente institucional local para fazer este fórum capaz de propor mudanças rurais. O estudo mostra que qualquer mudança institucional não ocorre rapidamente; as transformações dependem de cada particular contexto histórico. A conclusão que o caso de Igarapé-Açú oferece é que em um ambiente onde existem grandes conflitos políticos, há a necessidade de maior tempo para se criar vínculos entre os atores rurais.

Palavras-Chave: Parceria. Governança. Desenvolvimento Rural. Desenvolvimento Municipal.

\begin{abstract}
Asociación en espacios de gobernanza: el caso del Foro de Desarrollo Municipal de Igarapé-Açú, Pará, Amazonia
Resumen

El artículo analiza cómo la asociación entre el gobierno y las organizaciones locales en los espacios de gobernanza afecta el desarrollo local. El objetivo es plantear cuestiones críticas sobre el concepto de asociación y sobre la eficacia de la asociación para el desarrollo municipal. Para ello, el artículo aborda la asociación como teoría central. Específicamente, la investigación analiza en qué medida la asociación es una estrategia eficaz para el desarrollo local en zonas históricamente caracterizadas por conflictos entre el gobierno y las organizaciones locales en el estado de Pará, en la Amazonia brasileña. El estudio se centra particularmente en el municipio de Igarapé-Açú, ubicado al noreste del estado de Pará. Se eligió este municipio por ser un caso único de asociación entre el gobierno y las organizaciones locales desde el año 2008 , cuando se creó un espacio de gobernanza para establecer un proceso de asociación, denominado Foro de Desarrollo Municipal (FDM). Metodológicamente, el estudio de caso se llevó a cabo a partir de un análisis cualitativo de los datos obtenidos a través de documentos y entrevistas semiestructuradas con informantes clave. El artículo demuestra que el gran desafío para la construcción de alianzas entre las organizaciones gubernamentales y locales no reside en su capacidad de representar al Estado y a la sociedad civil en un foro de gobernanza, sino en su capacidad de cambiar el entorno institucional local para que este foro pueda proponer cambios rurales. El estudio muestra que ningún cambio institucional ocurre rápidamente; las transformaciones dependen de cada contexto histórico particular. La conclusión que el caso de Igarapé-Açú ofrece es que en un ambiente donde hay grandes conflictos políticos es necesario más tiempo para crear vínculos entre los actores rurales.
\end{abstract}

Palabras clave: Asociación. Gobernanza. Desarrollo rural. Desarrollo municipal. 


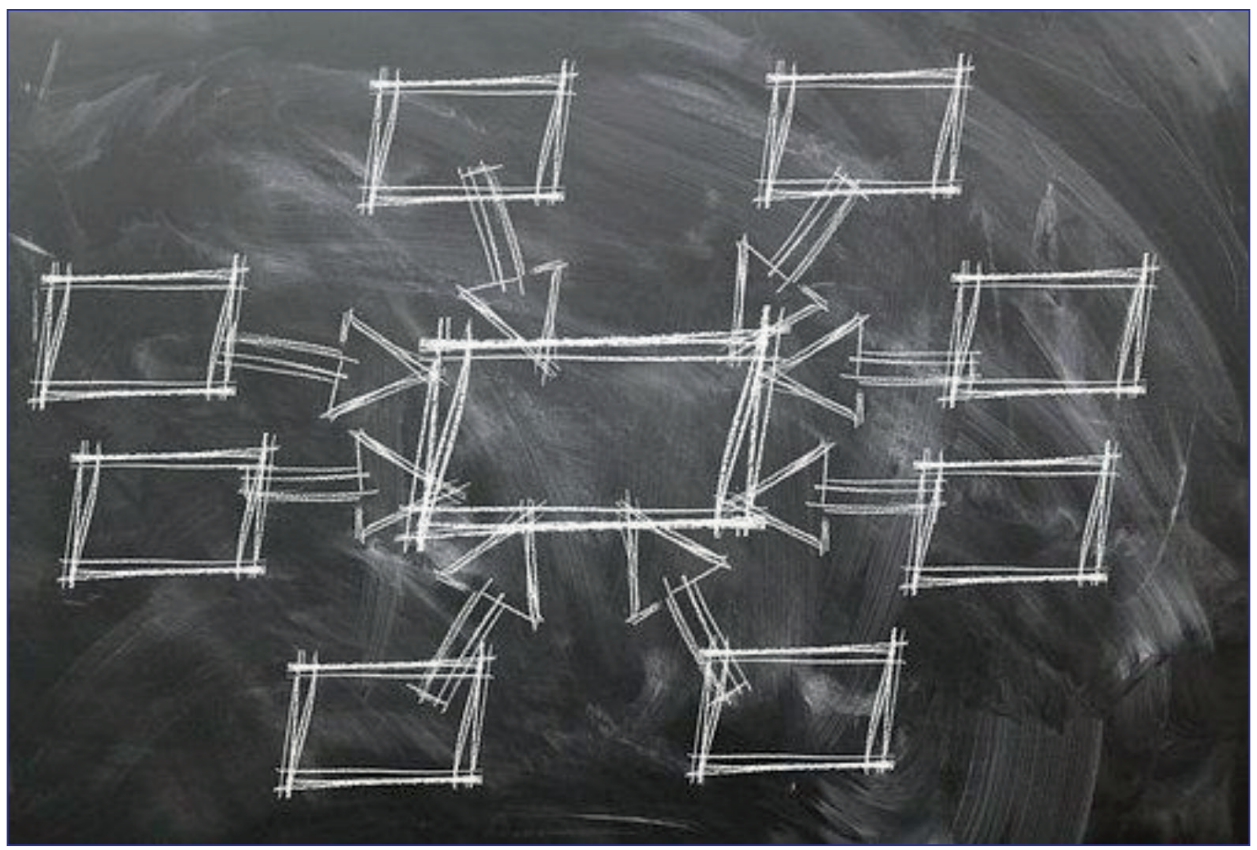

\section{INTRODUCTION}

This paper attempts to understand how partnership between local organisations and Government inside governance spaces affects local development. Particularly, it explores to what extent partnership is an effective strategy for local development in areas of historical conflict between local Government and the local organisations in Brazilian Amazonia.

The study attempts an understanding of the relationships that have emerged between Government agencies (GA) and local organisations (LO) in the planning and implementation of local development programmes at municipal level. It focuses specifically on the municipality of Igarapé-Açú, located in north-east of Pará State. Igarapé-Açú was chosen because it is a singular case (Yin, 1994) of GA - LO partnership since it was created in 2008 a governance space to carry out a partnership process called Municipal Development Forum (MDF). From the GA - LO partnership inside the MDF it was carried out a municipal development diagnosis; created a municipal development planning; and, elaborated rural projects for local development.

Local organisation is taken to mean all membership of non-governmental organisations both voluntary and non-voluntary that work for local development in the area involved (UPHOFF, 1982). Government agencies is its turn are federal, regional and local governmental organisations that support municipal projects and programmes for local development.

In Brazilian Amazonia, to promote favourable conditions for planning, resource decentralisation and social accountability, new forms of organisation involving social participation have been introduced as part of the political space for local development. In the local context, the most important of these organisations have been the committees, councils and forums. They are the governance spaces where GA and LO have built relationships to define the direction for local development at municipal level. In the Brazilian Amazonia they are new and innovative mechanisms that offer a great deal of possibility for strengthening citizen participation as right in the governance process. In fact, there is a belief that LO participation in local planning and implementation leads to a greater level of efficiency and effectiveness of investment and helps to promote greater democracy at municipal level (FLORISBELO and GUIJT, 2004, p. 202). LO participation in local planning and implementation has been translated into political discourse as 'partnership' between state and civil society. Although partnership is assumed to lead to

Image source: Pixabay. Available at: https://pixabay.com/pt/photos/parceria/ Accessed on Sept. 14, 2017. 
efficiency and effectiveness and citizen participation in the governance process, there has been some difficulty in ensuring that it is happening in practice. Then, the aim of this paper is to arise some critical issues about the concept of partnership and on partnership effectively for municipal development in Pará state, Brazilian Amazonia.

Methodologically, the case study research which this paper is based was carried from a qualitative analysis. The data was gathered from documents and semi-structured interviews carried out with 09 of 15 members whom were key informants with considerable involvement in partnership process: They were 04 LO' members, 02 Pará-Rural' staff members (one manager and one consultant), 02 LG' staff members and 01 member from the Federal government agency called EMBRAPA.

\section{GOVERNANCE SPACES AND PARTNERSHIP}

Partnership has emerged as a new institutional arrangement through which to deal with a variety of societal concerns such as environmental improvement (TRICKER, 2000), regional and economic development (BENNETT and KREBS, 1994) and urban regeneration (FALCONER and ROSS, 2000). Despite the rapid growth in their number, scope and influence, there is still a need for further work to understand the nature of these partnership arrangements in general and collaboration for local development in particular. In the literature, little attention has been given to the working of inter-organisational arrangements for local development - how they are formed, what makes them flourish, what makes them effective and what makes them fail. As stated by Gaventa (2004, p. 35), in examining the spaces for participation we should ask how they were created and in whose interests and with what terms of engagement. Partnership is defined here as consistent and continuous interactions between local Government agencies and local organisations.

Although since 1990s the municipalities in Brazil have incorporated the principle of participation in planning and established new institutional arrangements to support the process of governance, so far there are little evidences of how these partnership arrangements between state and civil society reflect cooperation between the organisations and promotes a better equilibrium of the interests and priorities of the local Government agencies and local organisations. Partnership for local development involves understanding interactions from a number of different perspectives. These include social capital, political competitiveness, local norms and procedures and organisational management capacity. In the local context, these factors coexist and interact with each other affecting the construction and performance of partnership (VASCONCELLOS SOBRINHO and VASCONCELLOS, 2012a).

According to Vasconcellos Sobrinho and Vasconcellos (2011), literature on development has located the concept of partnership into two different streams with low dialogue between each other: in the first stream, partnership is understood as a result of the existence or construction of social capital (OSTROM, 1997; HARRISS, 2000) and then it depends on the existence of trust and self-organisation (HARRISS, 2000, p. 236) of the partners. This view brings the ideal perspective that partnership only flourish inside claimed spaces. In the second stream, partnership is understood as resulting from the roles of formal and political institutions (VASCONCELLOS SOBRINHO and VASCONCELLOS, 2012a). From an institutional-based point of view, partnership in any context is influenced by the incentives and opportunities created by prevailing institutional frameworks and innovative organisations. Then, cooperation emerges in the institutional-based point of view by incentives of supportive institutions and organisations promoting and valuing innovation for development. From this perspective, partnership emerges only inside invited spaces.

However, the reality is more complex and different forms of partnership exist from diverse type of transaction between cooperating partners. A central issue raised in this work is how to build and maintain a shared commitment between Government and Civil Society represented by different local organisations amongst a range of interests that are long-entrenched with behaviour which they saw each other as enemies.

Partnership as an efficient 'soft technology' for local development will be better understood if empirical evidence is sought on the dynamics that characterise the interactions between Government and LO. However, as pointed out by Gaventa (2004, p. 35), examination of participatory spaces cannot be limited to such questions as for whom and how the space was created. This is because these spaces exist in dynamic relationship to one another, and are constantly opening and closing through struggles for legitimacy and resistance, cooptation and transformation. Thus, partnership goes beyond invited and claimed/created spaces. 
The partnership between LO and LGA in Brazilian Amazonia has been built after a long history of political and ideological conflicts between them. LO viewed, and in some cases still view, the state as an opponent of their local interests. On the other hand, the state, ${ }^{1}$ and particularly the LGA at municipal level, viewed LO as a threat to their political power. This misunderstanding has its origins in the different types of project that each one has for local development and also in the political practice of local authorities marked by corruption, coronelismo, clientelismo and oppression.

The 2000s has seen the establishment of partnership as a key tool for municipal development in Brazilian Amazonia. Partnership has come to be seen as a cost-efficient and effective mechanism for the implementation of development programmes and projects. Partnership has also been viewed as bringing significant benefits to municipal rural planning such as resources availability and legitimacy in their own right, particularly in terms of developing socially inclusive communities. As a result of these understandings, partnership has been applied to both political discourse and developmental projects by local state and local organisations as a tool for coproduction between government and civil society for public goods and services (OSBORNE, 2010).

Under the debate of the importance of the engagement of the civil society with the state, the discussion about partnership is accompanied by a concern for governance (STREN and CAMERON, 2005). Governance in the context of partnership means news forms of relationships between civil society, Government and Market to carry out development programmes that involves transparency, accountability and improvement of the efficiency of public programmes and services (VASCONCELLOS SOBRINHO and VASCONCELLOS, 2011; VASCONCELLOS and VASCONCELLOS SOBRINHO, 2015). Thus, governance means a new pattern of management which in some way the partners share valour, ideas, power and resources in favour to a common aim.

\section{THE PARÁ-RURAL PROGRAMME AND ITS INFLUENCE ON LO-LGA PARTNERSHIP IN IGARAPÉ-AÇÚ}

In 2005 the Pará Government created by low an integrated rural development programme called Pará-Rural. This programme aims to alleviate rural poverty from generation of work and income to rural families with very low-income. For that, the Pará Government had a financial agreement with World Bank in 2007 and in 2008 the programme started up. Since then, ParáRural has been one of the most important credit programmes for small-scale low-income agricultural producers in Pará carried out by state government.

The programme is managed by an extraordinary agency called Pará-Rural which is linked to the Secretary of Economic Development and Incentives for Production. The agency was specifically created to support family-based agriculture as a way of promoting sustainable, local (municipal) development under principles of decentralisation, democracy, transparency, partnership and social responsibility. The programme is divided into three principal components to respond to the rural structure in Pará state: (A) Productive Investments; (B) Land Use Planning; and (C) Public Policy Development. There is also a managerial component. The first and second principal components were the programme's focus in the first five years although the third one was fundamental to transform the programme in a long-term objective; however it was the last one to be carried out. The Productive Investments Component (PIC) is the most influent on LO-LGA partnership in Igarapé-Açú.

PIC's aims are especially focused on supporting family-based agriculture infrastructure and productive performance. The component is divided into two subcomponents: (1) rural loans for small producers and (2) infrastructure and municipal service support. The first subcomponent focuses exclusively on credit for planting and harvesting. The second subcomponent is for municipal infrastructure improvement in terms of goods and services.

To take part in the Pará-Rural programme each municipality must create its own Municipal Development Forum (MDF) and a Municipal Development Plan (MDP) and its own agenda of implementation. In fact, The Pará-Rural's design is very similar to Pronaf Infrastructue Programme, a Brazilian Government programme carried between 1997 and 2003. The Pronaf (National Support Programme for Family-Based Agriculture) aimed to support family-based, small-scale agriculture infrastructure and productive performance (ABRAMOVAY and VEIGA, 1999; ABRAMOVAY and PIKETTY, 2005).

${ }^{1}$ Although state and Government are two different concepts, in this work they are used synonymously. 
The Pará-Rural's requirements are part of the financial agreement with the World Bank (WB). In WB design there is a belief that these planning tools have a positive influence on rural communities and local state cooperation and consequently on rural outcomes, irrespective of the various factors that influence its final outcome.

"Pará-Rural's strategies are based on partnership between, regional and municipal entities, private sector and familial agricultural workers and their local organisations."

Pará-Rural folder

In Pará-Rural there is also a belief that participation by local organisations in rural planning and implementation leads to a greater level of efficiency and effective investments and helps to promote greater democracy in the rural sector (ABRAMOVAY, 2002; ABRAMOVAY and PIKETTY, 2005). Local organisation participation in rural planning and implementation has been described in official documents and in political discourse as 'partnership' between the state and civil society (PARÁ-RURAL, 2014).

In practice, Pará-Rural has been criticised for an absence of links between its subcomponents and its management structure (LADISLAU, GOMES, VASCONCELLOS SOBRINHO et al., 2010). However, the programme has been commended for bringing the different rural actors together (from public sphere, civil society and market) to elaborate, implement and evaluate a plan of common interests and to lead the way in efficiency and effectiveness for the use of public resources (MATTEI, 2001).

Although partnership is assumed to lead to efficiency and effectiveness for rural development, there is some difficulty in ensuring that it is working in practice. Definitions of Municipal Development Forum (MDF) and the elaboration of a Municipal Development Plan (MDP) do not necessarily mean full collaboration between the parties involved. Although the Pará-Rural programme has incorporated the principle of participation in planning and established new institutional arrangements to support this process, there is evidence which suggest that these arrangements have not increased full cooperation between the involved organisations. This is because the relationship between the partners has ceased as soon once the resources is finishing. If the forum and the plan are to achieve long-term objectives such ending of activity indicates that partnership is time limited.

“(...) While there were resources the forum worked (...) there were many conflicts, but our relation was alive (...) however, when the resources started to finish, the partnership also started to decline (...) it was not a partnership for rural development, it was a partnership for the use of the Pará-Rural's resources (...)"

Local organisation staff member.

"(...) it is true, our [local government and local organisations] relationship slowed down after the end of the Pará-Rural resources (...)".

Local Government staff member.

Equally, there is evidence that partnership has not fully reflected participation and empowerment of people who historically have been excluded from the development process. Issues of who is participating and what interests they represent are still contradictions within the participation process. It is not clear how partnership has promoted balance between the interests and the priorities of the state agents and local organisations - and their members. This is because reconciliation of different interests always implies some concessions in favour of the other partner. However, in a relationship where the concession to another partner may mean losing political power, then no one wants to concede.

"(...) they [leaders of local organisations] wanted that we [local Government] accepted the proposal of participation of every local organisation of the municipality as a member of the forum (...) it would be the subordination of the Government to these organisations (...)."

Local Government staff member.

The MDP's link with regional agencies and banks shows that in fact there is some "collusion" with state interests. This is because definitions of local projects were created according to plans from the regional (state) Government for the area (north-east of Pará). However, it is essential to state here is the influence that a credit programme (Pará-Rural) exerts on partnership formation between state and local organisations. 
The credit policy offers a good portrayal of the emergence of partnership between state and local organisations in Pará. However, rural partnership performance involves understanding the interaction of other different perspectives. These include political competitiveness between the rural actors and the networks established by them in this context. In rural Pará, political competitiveness and political networks coexist, interact with each other and affect substantially the construction and performance of partnership.

\section{PARTNERSHIP AS A TOP-DOWN AND BOTTOM-UP PROCESS}

The evidence put forward in Igarapé-Açú shows that partnership results from formal and political institutions (TENDLER, 1997; EVANS, 1997; LAN, 1997; HELLER, 1997). From the implementation of the Programme Pará-Rural, partnership was created from invitation of Pará government to LO to participate in the process of local (municipal) diagnosis and planning in order to have financial support for economic investments and productive projects. Accordingly, the World Bank only would support the government state planning if local society and municipal agents work together.

However, rather than being influenced exclusively by the Pará-Rural Programme, the evidences show that partnership also emerges from a bottom-up process with a significant contribution from social movements. The social movements started in Igarapé-Açú in 1990 and in that time they requested more participation in planning and governance. Thus, they were able to influence changes in the credit policy that, in its turn, brought new arrangements and substantial modifications to the rural sector. These arrangements, which included the creation of new local organisations, the creation of rural development forum and rural development plans, were certainly the main causes of bringing together, at municipal level, local Government and both existent and new local organisations. The actual pattern of partnership for rural development in is therefore part of the dynamic relationship which both the state and social movement have influenced.

The 'new political space' is a mix of what Cornwall (2002, p. 24) classifies as invited spaces and claimed/created spaces suggesting a continuum between them. Cornwall (2002, p. 24) define 'invited spaces' as those into which people (as users, as citizens, as beneficiaries) are invited to participate in various kinds of decision spaces as is the case of the constitutionalcreated committees in Brazil. The same author refers to claimed/created spaces as spaces which are claimed by less powerful actors from or against the power-holders, or created more autonomously by them.

Before 1990s, the policy established by the federal Government for the rural area development in Amazonia did not take account of the family-based, small-scale producers (COSTA, 1995; VASCONCELLOS SOBRINHO and VASCONCELLOS, 2012b). The exclusion of family-based, small-scale producers was linked to others factors such as the political rural elites' dominance at local levels. These reasons led to the divisions between Government (at federal, regional [state] and local levels) and the small-scale agriculturalists. Because of these divisions, very little dialogue and a high level of distrust has been prevalent between Government and small-scale rural producers.

The new scenario created by the Pará-Rural in carrying out a new credit policy model meant that both local Government and family-based, small-scale rural producers had to enter into dialogue in order to access financing. The rules for credit access required the formation of a Rural Development Forum with participation of both local organisations and small-scale producers. These rules had two opposite outcomes. On the one hand, they pushed local Government to share some political space that thus far had been the preserve of the state's institutions and their agents. On the other hand, they forced local organisations and social movements themselves to adapt to working closely with the Government and to put forward effective proposals for rural changes. As said, until the beginning of the 1990s, local organisations and social movements acted almost exclusively as opponents of Government and with no alternative projects for rural development.

“(...) slowly the rural movement has advanced to a real proposal for rural development. Firstly, the movement had to show that the established policy did not suit family-based agriculture, then the social movement confronted the Government about land and brought attention to rural violence, then the movement claimed financing (...) and I think that now there is a feasible proposal for familybased agriculture (...)."

EMBRAPA (Federal Agerncy) staff member 
The experience of Igarapé-Açú shows that even in areas where local Government and local organisations stand in opposition to each other, a new political space may be built up and in some cases, in a short period of time. However, the same experience shows that for this to occur, at least two factors are relevant. These factors are: (a) existence of top-down rules and regulations that force the state and organisations of civil society to work together and (b) presence of a political environment that facilitates state and civil society working together. Absence of these factors does not prevent collaboration between the rural actors entirely; however it requires other elements for collaboration such as implementation of small projects of development by external donors and/or NGOs that are not present in most municipalities in the region.

However, the history of Brazilian Amazonian planning and the social movement shows that rules and regulations in favour of more vulnerable people do not emerge without pressure from the bottom social movements. In Igarapé-Açú, the active participation of the Rural Workers' Unions in the regional (state) social movements was fundamental in strengthening the proposals for changes in the rural sector. Carried out by FETAGRI (Pará State Federation of Agriculture Workers), changes in the rural sector came about and are still coming about from struggle and/or democratic confrontations between organisations of family-based, small-scale rural producers and different levels of governmental administration. This shows the importance of intermediary NGO for making links between grassroots movements and local organisations with different levels of state agents (VASCONCELLOS and VASCONCELLOS SOBRINHO, 2015).

The history of the social movements in Para state and Amazonia as whole has shown that social movements were and are able to influence credit access and advocate for the inclusion of family-based, small-scale rural producers in the credit policy. The more recent proposals from the social movements in Amazonia are for the establishment of a link between rural production, preservation of the environment and financing under the concept of productive conservation (HALL, 2000; VASCONCELLOS and VASCONCELLOS SOBRINHO, 2012) that has been accepted and carried out by federal Government in a series of financial programmes.

However, local organisations and social movements are inter-related and their roles extremely mixed. Although the relationship with the state at federal and regional (state) level has passed from confrontation/conflict to confrontation/proposals, the evidence gathered in this study shows that at municipal level the local organisations have not made the distinction between political and social movements. At local level, the most active local organisations (as is the case of the association called Amiga) are still predominantly assuming the function of social movements. They have had or created barriers to collaborating with the state at local level. These mixed-up roles have happened even in places where the political environment facilitates a collaborative attitude such as in Igarapé-Açú.

Although local Government assume the discourse of partnership, the acts and attitudes of its agents towards collaboration with local organisations have made such discourse difficult to put into practice. For instance, local Government agents take a hierarchical view of the relationship between local Government and local organisations.

“(...) They [local organisations] have to understand that the last word has to be from the Pará-Rural (...) the fact that we work together in the forum does not mean that we have to do everything they want (...) If so, what is the role of the Pará-Rural?"

\section{Pará-Rural manager.}

Local organisations in their turn advocate more space for dialogue and proposals from the family-based, rural producers' point of view. According to one influential LO leader in Igarapé-Açú, regional (state) Government is not used to sharing.

“(...) They [Pará-Rural] still want to impose their proposals (...) they are not used to sharing ideas and accountability (...) If they do not lead the meeting they do not come (...) we called them many times for dialogue but they will only meet if we accept their ideas (...)."

Head of a local organisation.

The experience of Igarapé-Açú has shown that the state's position is not solely linked to legal arrangements. It is also linked to change in its agents. These changes in turn depend on the capacity of state agents to absorb new forms of interaction with rural people. 
"(...) it is difficult for them [local Government staff] to change their views quickly (...) for many, many years they possessed the knowledge [about production, cultivation] and the caboclo did not (...) nowadays we have to recognise the importance of the caboclo's knowledge (...) there is a need for [staff] renovation (...) the concept of participation is something very new for them (...) the participatory diagnosis and planning were pioneering in all the state (...)."

Pará-Rural Consultant.

Local Government agents also treat local organisations and their constituents as beneficiaries of governmental programmes and impede the most vulnerable groups from accessing financing and the possibilities of changing their livelihood with this credit.

"(...) after some time working here we know who is who. We know who is able to carry out a project and who is not. We just send to Pará-Rural for getting credit, the people who have the ability [to execute a project] (...)."

Pará-Rural manager.

Based on the premise that partnership is more effective if partnership is developed and sustained by trust (FOWLER, 1997; HARRIS, 2000; DOLNY, 2000), rural actors were asked: (a) if they trust their partners; (b) to evaluate their relationship within the context of the MDF. Nearly all respondents (95\%) said that the relationship between the actors is being superficial and dependent on political factors.

“(...) we always have a 'pe atras' approach[feet behind - it means not believing in something] with the government (...) we do not believe them at all (...)."

Head of a local organisation.

The lack of trust between the members of the MDF always causes conflict. There are permanent concerns from local organisations about favouritism from local Government. However, it depends on the level of political relationships that some members have with each other.

Taking into account the stage of relationship between the actors involved in the MDF and the almost total lack of meetings after the conclusion of the planning supported by Pará-Rural, one can say that if trust was not a sine qua non condition to the formation of the partnership, it seems to be an important factor in its maintenance. Disappointing experiences and local Government failures in carrying out its part of the projects have made the actors involved in the process doubt each other and consequently remain doubtful for future relations. This absence of trust may be prevalent during the construction of a partnership, but it cannot be dominant during the management of a partnership. If trust has to be achieved in order to construct the ideal partnership (Fowler, 1997), the questions that emerge are how to build up trust between organisations that are on opposing political sides, with different interests and priorities and how to build trust in short time, in an environment where distrust has been prevalent for decades.

\section{MUNICIPAL DEVELOPMENT FORUM (MDF) AS A SITE OF PARTNERSHIP AND GOVERNANCE}

If the MDF is able to establish partnerships between Government and civil society at local level so as to improve decision making for local priorities and monitoring rural development programmes and projects, it will have made a significant contribution to participation in the governance of rural systems. This will be so, not only because this participation will be carried out through organisations that are fundamentally chosen by local people, but also because it is supported by policies that are formulated through the widest possible engagement of people and local organisations. However, in an evaluation of municipal committees in a different area of the country (ABRAMOVAY, 2002; VASCONCELLOS SOBRINHO, 2009) most were not thought to work and those that did felt they were dominated by the vested interests of local authorities (ibid.).

However, the case of Igarapé-Açú differs from the examples above. The creation of MDF happened in a positive political scenario that facilitated its creation. The mayor of Igarapé-Açú came from the same political alliance of state government 
and then the municipality was taken as priority. Promotion by and involvement of organisations was led by the local Rural Workers' Union and the local family-based associations. The Prefeitura came over to the cause when the Pará-Rural program showed that it was able and ready to apply for resources. It is important to underline these issues because they highlight the importance of a favourable political scenario for construction of cooperation in a short period of time. They also denote the importance of links between local organisations and social movements so that state and civil society can move closer together.

“(...)Everything started when the state Government launched Pará-Rural program. (...) The Pará-Rural requested the formation of Municipal Development Forum and Municipal Development Plans (...) We [Amiga Association] were already ready since we were part of the social movement involved in the Pará-Rural demands (...)."

Local Organisation member.

Events in Igarapé-Açú illustrate that civil society may engage fully with the local state in order to work together in cooperation. However, they demonstrate that a favourable political scenario is important for such cooperation. Without the possibilities of political dialogue between the different actors involved in the rural system, forums for municipal development may be a site of permanent inertia, with very little proposals. The forums may also be vulnerable to 'imposition' if Government interests include or co-opt committee members.

However, like others spaces of governance, the MDF in Igarapé-Açú also shows existence of conflicts, hierarchy, dominance and subordination. External consultants that acted in Igarapé-Açú emphasises that conflict and power dispute stills present.

“(...) The creation of forums for municipal development was a great advance in terms of people's participation in governance; in the accountability of the use of public resources (...) this is improvement of the democratic process (...) however, there is a long way to go before this space to be effective (...) first, people need to know the role of the Forum (...) the MDF is yet another space for power disputes (...) the culture of conflict is installed in the municipality and the forum' members are learning another paradigm (...) they are learning to be conciliatory (...) I think this is a long process; [this demands] years, perhaps decades (...)."

\section{Pará-Rural Consultant}

Participation in the MDF initially occurred due to an inadequate understanding of the role of this type of committee. This study identified that was common for participants of the MDF to confuse the role of this forum with the roles of other spaces for governance created to supervise the use of resources such as the Municipal Health Council and the Municipal Education Council.

“(...) It was interesting because the forum' members did not understand its own role (...) just some members of the forum had some knowledge about its meaning (...)."

EMBRAPA (Federal Agerncy) staff member.

This confusion is because from the 1988 Brazilian Constitution, there was a proliferation of spaces for social participation and governance at municipal level that were created by law to play different roles (ABRAMOVAY, 2002; SOUZA, 2004). The MDF's functions, however, include other duties apart from the social control of public funds and public action (VASCONCELLOS SOBRINHO, 2009). It should include planning and execution of projects for development and rural changes to be reached in short, medium and long periods. However, if there are no direct financial resources involved in it, motivation for participation in the MDF is minimal, if not non-existent.

“(...) I think we should evaluate our work (...) we had some progress, some advances (...) we were the pioneers in Pará (...) Sometimes I think we were mistaken in abandoning the Forum (...) nowadays there is no demand for meetings (...)."

Local Government staff member.

Misunderstanding and absence of enthusiasm about MDF roles in the present restricts participation to heads of local organisations, particularly to the traditional and/or older local organisations. This study identified that members of other 
local organisations refuse to participate in the MDF meetings because they do not want to be involved in planning activities that are perceived as not providing direct (and therefore easy) access to financial resources.

“(...) we cannot waste our time participating in planning for the next five or six years (...) we need changes right now (...) we need [financial] resources now (...)."

\section{Local Organisation member.}

As there are at least four municipal committees or forums (Health, School Dinners, Infancy and Adolescence, and Urban Development) the heads of these local organisations tire of participating in many spaces of participation and governance and thus complain about the volume of work.

Civil society participation in the MDF is not restricted to local organisations once the Forum allows participation of other private organisations interested in the development of the municipality. However, there are poor engagements of other representatives of civil society in the Forum. Integrated municipal development is a wider concept and involves multiple actors that if not involved in a process of integration may distort the process.

“(...) Our idea of the role of a forum for rural development was, first of all, to listen to everybody, to give an opportunity to all organisations in civil society, public and private, governmental and non-governmental, profit and non-profit to offer opinions and to contribute to the development of the municipality (...) if you involve everybody you legitimise the process, you create a favourable environment (...) but if you exclude someone they may cause trouble (...) to make trouble is easier rather than to collaborate (...)."

\section{Pará-Rural manager.}

Making family-based, small-scale rural producers a priority of municipal development does not mean the exclusion of other actors. Other actors that are not family-based, small-scale rural producers do play significant roles in the rural sector and the municipality as whole once they may help or obstruct the development process. In Igarapé-Açú the absence of large-scale farmers to discuss their interests and to contribute an understanding of prices and market was also felt. Consequently, Municipal Development Plans is too much concentred to family-based, small-scale rural development plans. This kind of phenomenon is very similar to other municipal development and regional forums in Brazil such as the Borborema's Rural Territory Forum in the Paraíba state (DELGADO, 2010). Like Borborema region, Igarapé-Açú is distinguished by a remarkable role of civil society for rural development, particularly family-based, small-scale rural movements since the beginning of 1990s. In fact, large-scale farmers voluntarily exclude themselves from the process of territorial development. Piraux and Bonnal (2008) also analysing the case of Borborema point out existence of two reasons for this self-exclusion. Firstly, because large-scale farmers do not agree with the territorial development process led by Government and small-scale family-based farmers; and secondly, because they have their own and individual dynamic for rural development.

Though family-based, small-scale development was prioritised, it did not mean that this part of the rural sector was fully taken care of. The distance and absence of information also restricted participation of ordinary people in the MDF even as ordinary spectators. In Igarapé--Açu, lack of time, resources and (political) organisation was deemed the cause of excluding communities there such as happens in others Brazilian forums of participation for territorial development (CANIELLO, PIRAUX and BASTOS, 2013).

If partnership relates to the involvement of socially marginalised peoples and communities in decision-making over their own development initiatives, decisions and resources (ABRAMOVAY, 2002), then one can say that the MDF as a new political space for social inclusion has been limited in the same way of the new Brazilian territorial policy forums at local level (CANIELLO, PIRAUX and BASTOS, 2013; DELGADO, 2010). Certain changes are needed: firstly, more financial resources are needed to meet the people's needs inside the communities; secondly, more external support is needed to organise the community formally; thirdly, political interests must bring the claims of these communities to the MDF. Respondents have been sceptical when evaluating ways to increase participation of the most vulnerable groups in rural planning and this is linked to the capability of the MDF to carry out this job. 
In Igarapé-Açú, no one in the MDF could be said to be concerned about improving participation and/or to be effective in their tasks except when there is an obligation to do so. However, its experience has shown that civil society - government cooperation is possible for social change and development although it is a slow and time-consuming process.

\section{ROLE OF EXTERNAL ACTORS}

Fieldwork research revealed that external actors played a fundamental role in strengthening the political power of the Community Based Development Associations (CBDAs) and their skills in developing community projects. This was the case of the (a) Amiga and (b) Vila União associations. From the acquisition of external support, the CBDA leaders were able to benefit from the Rural Workers' Unions and to create powerful rural workers associations to propose alternative projects for community development. Rural community resistance to vertical structures and to exclusive reliance on local Government (as in the cases of Amiga and Vila União associations) resulted from a process of engagement of organisations with external actors.

This study demonstrated that participation in the formal political arena was fundamental to spreading the aims of community development projects, to link local organisations with local Government and to facilitate dialogue between them. This means that to reach rural development at municipality level there is no other arena for relations between local Government and local organisations except within political relations.

However, the political culture in Igarapé-Açú is marked by favouritism. Both local Government and local organisations use their political power to prioritise the people and/or communities that are politically engaged with them and to exclude those who have less political weight in terms of voting.

“(...) our community is small (...) and very far away (...) it is very rare to see someone there (...) except during elections (...) there is not much interest in our community because we are few people (...)."

Local Organisation member.

The culture of favouritism increases the chances that the most vulnerable groups will continue to be reliant on local Government. If local Government controls information and financial resources, its chance of co-opting the leaders of the most vulnerable groups is higher than other organisations like the Rural Workers' Unions - the organisations that in principle represent rural peoples' interests and priorities.

It was found by this research that inside the new arrangement for civil society participation in local Governance, regional (state) Government itself tried to create favourable conditions for its own power interests. Local Government created dependent and weak local organisations to participate in the forum and consequently in the MDP. On the one hand, Government (both local and regional [state]) offered ${ }^{2}$ a chance for some rural communities to participate in the discussion of their own interests. However, on the other hand, this participation was linked with the Government's intention to validate its own job.

The chance for very poor communities to reject the Government's offers and to break the culture of favouritism is low if there is no other way of accessing resources, information and finance. Although local organisations try to develop conscientização (awareness), this works depends on available financial resources.

The trouble is that the 'favouritism' offered by Governments has not proffered possibilities of changes in the socio-economic structure of the communities. There is a great disparity between what is offered by both Governments and the needs and priorities of rural communities.

For areas with no tradition of community-state cooperation, the implementation of the MDF and MDP is likely to be critically important in order to link local Government and rural communities. However, initiatives that encourage rural communities to organise their own requirements and to change their forms of engagement with the local state have been dependent on external support.

2Prefeitura indicated the organisations who could participate in the MDF. 
(...) the support of FETAGRI was fundamental for the community to gain more independence and to be less reliant on the Prefeitura [council] (...)

Local Organisation member.

Fieldwork research revealed that the relations between local organisations and local Government have emerged in an environment of fragile knowledge about the significance of partnership and where power disputes have weakened the opportunity to create the prospect of secure and long-term relationships. The presence of external NGO in Igarapé-Açú has shown that external actors have been required in order to support a more effective dialogue between rural actors. This does not mean that all relationships between local organisations and Government need to be mediated by external actors. However, the case of Igarapé-Açú shows that where external actors are present acting as intermediary (VASCONCELLOS and VASCONCELLOS SOBRINHO, 2015), local organisations are more able to respond to the interests of their constituents, the understanding about the significance of partnership and the role of committees is better and the possibility of dialogue between local organisations and local Government has increased.

\section{INFLUENCES OF THE STRUCTURE OF POWER}

Fieldwork revealed that the actors engaged in the partnership process are, in general, aware of an involvement with political, institutional and financial power disputes. Both local organisations and state agents usually indicate (directly and indirectly) that they are on opposite sides in the relationship. Because of long political dominance of groups linked to rural elites, it is difficult to find local organisations leaders that accept Government leadership.

“(...) we cannot trust them (...) they just look for us during the elections (...) after our support; they leave us (...)."

\section{Local Organisation member}

In practice, this means that partnership for rural development in Igarapé-Açú was contradictory and created in an environment where absence of trust was prevalent. Programmes that were created and then implemented without prior agreement of negotiable and non-negotiable principles cannot be carried out without conflict. This does not mean that partnership can be carried out with no conflicts at all. Embedded relationships that suggest complete synergy between state and civil society as pointed out by Tendler (1997) and Ostrom (1997) is a utopia. However, for a partnership to achieve outcomes at local level, the actors could at least put their differences to one side, define clearly their aims and outline their complementary roles (LAN, 1997) in favour of the more vulnerable peoples. Insufficient understanding and constant disputes between the partners only serve to exacerbate the rural communities' disillusionment with so-called possibilities of improvement in their livelihoods.

“(...) I am 75 years old and I am tired of always hearing the same thing (...) Governments come and go and everything is still the same (....)."

Local Organisation member

“(...) everyone is tired (...) everyone is untruthful (...) no one believes in anyone (...)." Local Organisation member

Not only is this likely to cause partnerships to be artificial and weak in regard to the needs and aspirations of the more vulnerable communities, it also damages the already fragile relationship between them and local organisations and local Government.

"(...) it is difficult to believe (...) everyone is untruthful (...) sometimes they [local organisations leaders] are on one side and suddenly they change to the opposite side (...) It happens in every election (...)."

Local Organisation member 
The limited reciprocity between partners is endorsed by external NGOs that suggest that the relationship will not change for as long as the rural sector remains dominated by political interests associated only with elections and power.

Political interests and institutional management customs related to this culture mean that interaction with the most vulnerable rural communities is weak and dominated by ineffective practice for changes in favour of these communities. Any assumption of synergetic relation between Government and civil society is far from being achieved.

“(...) I do not understand this relationship as a partnership in favour to the poorest communities (...) what has been done? Nothing (...) one or two projects have been supported (...) what I see is that the Pará-Rural uses this discourse to say that they did it, they did that, and then to get votes to the state government during the elections (...)."

\section{Local Organisation Leader.}

Although the physical environment poses real problems for accessing the poorest communities and communicating effectively with them, it cannot be assumed that this is the only barrier to their involvement in the process of rural development. Financial resources and lack of interest in Government in reaching these communities are always regarded as obstacles to be overcome. I fact, geographical access is a recognised problem. However, the MDF and MDP are respectively the site and instrument where local organisations and Government should debate and propose alternatives forms to overcome this problem. They are also the site to attract more vulnerable communities to discuss their efforts, to show their financial limitations and to define a form of cooperation between them. However, contrary to the model of participatory governance where civil society has an active role (FLORISBELO and GUIJT, 2004), the model of partnership established in Igarapé-Açú is limited. Firstly, it is reduced to the participation of already existent (and formal) organisations. Secondly, it is reduced by excluding those, who in principle should be the main focus of development, the poorest and unorganised communities.

Less concerned with the inclusion of economically and socially marginalised groups in process of development, current leaders try to use the MDF space to access financial resources and to reinforce (in the case of local Government) or to secure (in the case of local organisation leaders) political power.

“(...) who has the money, has the power, isn't it? The greatest aim of both associations and prefeitura was to prioritise the projects and the communities that will be reached (...) certainly, these projects and communities were according to their political intentions (...)."

EMBRAPA (Federal Agency) staff member.

This is a great risk that MDF has offered is the 'institutionalisation of exclusion' with the pseudo-agreement of civil society representatives.

\section{CONCLUSION}

The creation of the MDF (and MDP) and its system of rural access to credit is a significant institutional innovation in Pará state public policy. It emerged as a mix of an invited space from Government and a claimed/created space by small-scale, family-based farmers what suggests a continuum between them. Although this innovation may be criticised for its low social participation and being controlled by local political power interests, the MDF has the potential to join state and civil society together for a rural transformation and to change the decision-making structures of areas dominated by vertical structures of power.

In Pará in general, and particularly in Igarapé-Açú the structures of local power are dominated by vertical configuration. With the creation of the MDF and the implementation of the MDP with the participation of local people, there have been great advances in the inclusion of rural people in the decisions that affect them. Family-based, small-scale producers that historically were neglected in the planning of rural sectors have been allowed to participate - at least in theory - in decision-making spheres that may have a great effect on their economic production and social reproduction. 
It cannot be asserted that this partnership has brought rural development for Igarapé-Açú as a whole or that the recent outcomes reached by them are exclusively the product of partnership. However, as a site of effective partnership between state and civil society in rural areas, the MDF has to engage with issues that so far have been neglected. Common with other studies (for example, MATTEI, 2015; VASCONCELLOS SOBRINHO, 2009) was the exclusion of the communities that are distant from the centre of the municipality and/or historically marginalised regions. This is because they do not have a constituted formal association and/or because they do not represent any political advantage to local Government or even to the more politically-motivated local organisations.

Although they have been invited, medium and large-scale farmers and also private local organisations have all been absent as they were deemed not part of the rural sector. The MDF has been treated as an exclusive organisation to attend to the interests and priorities of local Government and formally organised communities. If state - civil society partnerships for rural development means the inclusion of all sectors of civil society (including socially and marginalised communities) in municipality development initiatives, then one can say that in this respect the MDF have failed. Inclusion of all the different bodies in the rural sector is a sine qua non to improve the various levels of social integration and social support that are needed for rural development.

The reasons why the MDF were created and the ways in which they are formed reflect on the MDP of the municipality. The MDF was created to respond to World Bank exigency and the MDP consequently was started in order to have access to available resources. However, so far the MDP has narrowed the concept of rural development to just the growth of agricultural production and their targets are still concentrated on the cultivation of crops, fruits and honey. However, rural development is no longer exclusively focused on agricultural production alone and for example issues of land, health, education and training should be included and implemented as they have been incorporated in the recent territorial policy in Brazil (PIRAUX and BONNAL, 2008; MATTEI, 2015). Not only is this dependent upon a much deeper engagement with rural development, it also requires a reorganisation of the rural sector.

So far, the MDP has not taken the opportunity to create an innovative proposal for rural development involving all local actors. However, the stimulus for innovation depends on the capacity of the rural actors involved in the MDF and on the ability of these actors to negotiate the MDP plan with the various levels of Government.

However, both the MDF and MDP have been influenced by the political circumstances characterised by high levels of power disputes and an almost total absence of trust. Local Government staff and the members of local organisations are constantly disputing their political space and creating a problematical environment for the definition of common aims. Disputes inside the MDF not only affect those who are disputing the political space, but mainly affect the rural population who depend on the MDP to have access to loan from Pará-Rural and then to improve their livelihoods.

A great challenge for the construction of partnership between local Government and local organisations is not its capacity to represent the state and civil society in a rural forum, but its capacity to change the local institutional environment to make this forum able to propose rural changes. However, any institutional change does not happen rapidly; changes depend on a particular historical context. A conclusion that the case of Igarapé-Açú offers is that in an environment where there is great political conflict there is the need for more time to create links between the rural actors. In this case, the presence of external actors may facilitate these links. Organisations are responsible for changes in the environment and are the only vehicle to implement institutional changes.

Through the intervention of external agents with resources, more than just credit rights have been asserted and contested. Development interventions are about power as well as resources; contested rights are for social positions, respect and influence. Since rural development organisations institutionalise power in new ways, they are often the focus for challenging or renegotiating public status and position. Indeed, much is at stake in gaining control of local institutions linked to external resources (or failing this, in ensuring that they are effectively obstructed).

More broadly, an understanding of history and power suggests that present 'theories of partnership' are overly functionalist and draw excessively on rational choice theories of collective actions (famously stated by OLSON, 1965). Attempting to account for the strengths and weaknesses of institutions of common resource management in terms of the balance of individual costs and benefits gives little recognition to the fact that material interests are inseparable from social relationships. Moreover, choices are mediated by social institutions that involve shared assumptions about issues such as justice, fairness and reciprocity. The social and political meanings of 'common' or 'public' resources are constituted in culturally and historically specific ways.

While community institutions both inscribe social power and are subject to historical change, in popular development thinking they are conceived in strangely apolitical and ahistorical terms. 


\section{REFERENCES}

ABRAMOVAY, R. Conselho além dos limites. Seminário Desenvolvimento Local e Conselhos Municipais de Desenvolvimento. Porto Alegre: Seminário Desenvolvimento Local, 2002.

ABRAMOVAY, R.; PIKETTY, M. G. Política de crédito do Programa Nacional de Fortalecimento da Agricultura Familiar (PRONAF): resultados e limites da experiência brasileira nos anos 90. Cadernos de Ciência \& Tecnologia, v. 22, n. 1, p. 53-66, 2005.

ABRAMOVAY, R.; VEIGA, E. da. Novas instituições para o desenvolvimento rural: o caso do Programa Nacional de Fortalecimento da Agricultura Familiar (PRONAF). IPEA Texto para Discussão 641, 1998.

BENNETT, R. J.; KREBS, G. Local economic development partnerships: an analysis of policy networks in EC-LEDA local employment development strategies. Regional Studies, v. 28, n. 2, p. 119-140, 1994.

CANIELLO, M.; PIRAUX, M.; BASTOS, V. V. S. Identidade e Participação Social na Gestão do Programa Territórios da Cidadania: um estudo comparativo. Estudos Sociedade e Agricultura, v. 21, n. 1, p. 84-107, 2013.

CORNWALL, A. Making spaces, changing places: situating participation in development. IDS Working Paper 170, 2002.

CORNWALL, A.; GAVENTA, J. Participation in Governance. In: HUQUE, A. S.; ZAFARULLAH, H. (Eds.). International Development Governance. London: Taylor \& Francis, 2006. p. 405-413.

COSTA, F. D. A. Amazônia: modelos econômicos, ideologia e história. In: CASTRO, E.; MORUA, E.; MAIA, L. S. Industrialização e grandes projetos: desorganização e reorganização do espaço. Belém: UFPA, 1995.

DELGADO, N. Sociedade civil, Estado e protagonismo institucional no desenvolvimento territorial: avanços e obstáculos no caso do território rural da Borborema / PB. Raízes, v. 28, n. 1, p. 41-51, 2010.

DOLNY, $\mathrm{H}$. Building trust and co-operation: transforming the Land Bank. In: ROBINSON, D.; HEWITT, T.; HARRISS, J. (Eds.). Managing Development: understanding inter-organizational relationships. London: Sage \& The Open University, 2000.

EVANS, P. Government action, social capital and development: reviewing the evidence on synergy. In: EVANS, P. (Ed.). State-society Synergy: government and social capital in development. Berkeley: University of California, 1997.

FALCONER, P.; ROSS, K. Public-private partnership and the new labour government in Britain. In: OSBORNE, S. (Ed.). Public-private partnerships: theory and practice in international perspective. London: Routledge, 2000.

FLORISBELO, G. R.; GUIJT, I. Participatory municipal development plans in Brazil: divergent partners constructing common futures. In: HICKEY, S.; MOHAN, G. (Eds.). Participation: from tyranny to transformation? Exploring new approaches to participation in development. London: Zed Books, 2004.

FOWLER, A. Striking a balance: a guide to enhancing the effectiveness of non-governmental organisations in international development. London: Earthscan, 1997.

GAVENTA, J. Towards participatory governance: assessing the transformative possibilities. In: HICKEY, S.; MOHAN, G. (Eds.).
Participation: from tyranny to transformation? Exploring new approaches to participation in development. London: Zed Books, 2004.

HALL, A. Environment and Development in Brazilian Amazonia: from protectionism to productive conservation. In: HALL, A. (Ed.). Amazonia at the crossroads: the challenge of sustainable development. London: University of London, 2000.

HARRISS, J. Working together: the principles and practice of co-operation. In: ROBINSON, D.; HEWITT, T.; HARRISS, J. (Eds.). Managing Development: understanding inter-organizational relationships. London: Sage and The Open University, 2000.

HELLER, P. Social capital as product of class mobilization and state intervention: industrial workers in Kerala, India. In: EVANS, P. (Ed.) State-society Synergy: government and social capital in development. Berkeley: University of California, 1997.

LADISLAU, E. et al. Reflexões acerca de um novo modelo de gestão no meio rural amazônico. In: Anais do II Congresso Internacional de Tecnologia para o Meio Ambiente. Bento Gonçalves: UCS, 2010.

LAN, W. F. Institutional design of public agencies and coproduction: a study of irrigation associations in Taiwan. In: EVANS, P. (Ed.). State-society Synergy: government and social capital in development . Berkeley: University of California, 1997.

MATTEI, L. Programa Nacional de Fortalecimento da Agricultura Familiar (PRONAF): concepção, abrangência e limites. IV Encontro da Sociedade Brasileira de Sistemas de Produção, Belém, SBSP, 2001.

MATTEI, L. Políticas Públicas de Apoio à Agricultura Familiar: o caso recente do PRONAF no Brasil. Raízes, v. 35, n. 1, p. 01-15, 2015.

OLSON, M. The logic of collective action: public goods and the theory of groups. Cambridge, Massachusetts: Harvard University Press, 1965.

OSBORNE, E. The new public governance? Emerging perspectives on the theory and practice of public governance. London: Routledge, 2010

OSTROM, E. Crossing the great divide: co-production, synergy and Development. In: EVANS, P. (Ed.). State-society Synergy: government and social capital in development.Berkeley: University of California, 1997

PARÁ-RURAL. Programa de Redução da Pobreza e Gestão dos Recursos Naturais do Pará: primeira revisão do manual operacional. v. 1. Belém: Pará Rural, 2014.

PIRAUX, M.; BONNAL, P. Projetos coletivos de desenvolvimento territorial e multifuncionalidade da agricultura familiar: um estudo sobre o entorno de Campina Grande, PB. Estudos Sociais e Agrícultura, v. 16, n. 2 , p. 262- 292, 2008

SOUZA, C. Governos locais e gestão de políticas sociais universais. São Paulo em Perspectiva, v. 18, n. 2, p. 27-41, 2004.

STREN R.; CAMERON, R. Metropolitan governance reform: an introduction. Public Administration and Development, v. 25, n. 4, p. 275-284, 2005.

TENDLER, J. Good Governance in the tropics. Baltimore: John Hopkins, 1997. 
TRICKER, M. Rural Action for the Environment in the UK: developing partnerships and promoting learning through networks. In: OSBORNE, S.P. (Ed.). Public-Private Partnerships: theory and practice in international perspective. London: Routledge, 2000.

UPHOFF, N. (Ed.). Rural development \& local organization in Asia. New Delhi: Macmillan India, 1982.

VASCONCELLOS, A. M. A.; VASCONCELLOS SOBRINHO, M. A Socio-Environmental Development Programme in Action in Brazilian Amazonia. Brazilian Administration Review, v. 9, n. 1, p. 23-43, 2012

VASCONCELLOS, A. M. A.; VASCONCELLOS SOBRINHO, M.; Institutional Development for Good Governance: the role of intermediary NGOs in Pará state, Amazonia. Rev. Adm. Pública, v. 49, n. 3, p. 793-815, 2015.

VASCONCELLOS SOBRINHO, M. Partnership for Local Development: the relationship between government and local organisations in two areas of North-East of Pará, Amazonia, Brazil. 1. ed. Mauritius: VDM Publishing House, 2009.

VASCONCELLOS SOBRINHO, M.; VASCONCELLOS, A. M. A. Local Organisations Capacity and Its Influence on Partnership with Local Government for Rural Development in Brazilian Amazonia. Amazônia, Organizações e Sustentabilidade, v. 1, n. 1, p. 25-44, 2012a.

VASCONCELLOS SOBRINHO, M.; VASCONCELLOS, A. M. A. Social movement, public policy changes and partnerships building for local development. Interações (UCDB), v. 13, n. 2, p. 243-258, 2012b.

VASCONCELLOS SOBRINHO, M.; VASCONCELLOS, A. M. A. Statecivil society partnership: issues for debate and new researches. Organizações \& Sociedade, v. 18, n. 59, p. 701-717, 2011.

YIN, R. K. Case Study research design and methods. London: New Delhi, 1994.

Mário Vasconcellos Sobrinho

He is an economist and holds PhD in Development Studies from the Swansea University (United Kingdom); He is a senior lecturer at Universidade da Amazônia (Administration Postgraduate Programme) and Universidade Federal do Pará (Natural Resources Management and Local Development Postgraduate Programme, from the Centre of Environment - NUMA), Belém- PA, Brazil. Emails: mariovasc@ufpa.br; mario.vasconcellos@unama.br

Marco Antonio Carvalho Teixeira

He is a bachelor in social science and holds PhD in Social Science from the Universidade Católica de São Paulo; He is a senior lecturer at Business Administration School from the Fundação Getulio Vargas (FGV EAESP) / Govern and Public Administration Postgraduate Programme, São Paulo - SP, Brazil. Email: marco.teixeira@fgv.br 